\title{
DOI 10.26886/2520-7474.1(33)2019.2
}

UDC: $342.7: 347.9$

\section{THE IMPORTANCE OF HUMAN RIGHTS FOR DEMOCRACY AND THEIR JUDICIARY PROTECTION}

\section{K. S. Muzychuk, PhD of Law Sciences}

Lesia Ukrainka Eastern European National University, Ukraine, Lutsk

The topical issues of the importance of information rights and freedoms for the construction of a democratic society are considered. On the basis of the constitutions of the countries of the European Union, the legal essence of information rights and freedoms of the person is revealed; the place of information rights in the general classification of human rights is determined; highlighted the functions through which information rights and human freedoms affect the construction of democratic societies; It has been proved that judicial proceedings in the area of defending the information rights and freedoms of national courts of the countries of the European Union and countries that have embarked on the path to democracy have to be made taking into account that these rights and freedoms are the basis of democracy.

Key words: information rights and human freedoms; democracy; judicial protection; place of information rights in the general classification of human rights; the importance of information rights and freedoms in a democratic society.

кандидат юридичних наук, Музичук К. С. Значення інформаційних прав і свобод людини для демократії та особливість їх судового захисту/ Східноєвропейський національний університет імені Лесі Українки, Україна, Луцьк

Розглянуті актуальні питання значення інформаційних прав і свобод людини для побудови демократичного суспільства. На основі 
конституцій країн Європейського Союзу розкрито правову сутність інформаційних прав і свобод людини; визначено місце інфоормаційних прав в загальній класифрікації прав людини; виділено фрункції, завдяки яким інфрормаційні права і свободи людини впливають на побудову демократичних суспільств; доведено, що судочинство в питаннях відстоювання інформаційних прав і свобод людини національних судів країн Європейського Союзу та країн, які стали на шлях демократії, має здійснюватись із врахуванням того, що згадані права і свободи лежать в основі демократії.

Ключові слова: інформаційні права і свободи людини; демократія; судовий захист; місце інфрормаційних прав у загальній класифікації прав людини; значення інфрормаційних прав $і$ свобод людини в демократичному суспільстві.

Постановка проблеми. Прийнята 10-12 грудня 2003 року в Женеві Декларація принципів побудови інформаційного суспільства вбачає значення інформації для людства в «...загальному прагненні та рішучості побудувати орієнтоване на інтереси людей, відкрите для всіх і спрямоване на розвиток інформаційне суспільство ... щоб дати окремим особам, общинам та народам можливість у повній мірі реалізувати свій потенціал, сприяючи своєму стійкому розвитку та підвищуючи якість свого життя на основі цілей та принципів Cmamymy OOH (995_010) ma дотримуючись у повному об'ємі та підтримуючи Загальну декларацію прав людини (995_015)» [1] (Тут і надалі курсивом виділятимемо положення фрундаментальних документів, вплив яких на становлення демократії $€$ неоцінений; рекомендації комісій, які стоять на сторожі демократії в Європейському Союзі (далі - ЄС, Спільнота); конституційні положення країн демократії). 
Природно, що жителі різних держав світу, в тому числі, українці, прагнули жити саме в суспільстві, у якому їх права і свободи були б захищені судами.

Суттєві здобутки країн ЄС в становленні демократії викликали прагнення багатьох країн Європи вступити до цієї Спільноти. Перед країнами-претендентами на вступ ЄС поставив вимогу відповідати копенгагенським критеріям, схваленим на засіданні Європейської Ради у Копенгагені (червень, 1993 р.). Серед критеріїв: 1) «стабільність інститутів, що гарантують демократію, верховенство права, повагу до прав людини і захист національних меншин»; 2) країнипретенденти «повинні не лише закріпити принципи демократії $i$ верховенства права у своїх конституціях, але й гарантувати демократичні свободи, включаючи політичний плюралізм, свободу слова $і$ свободу совісті. Вони встановлюють демократичні інститути та незалежні органи правосуддя, органи конституційної юрисдикції; 3) забезпечити стан захищеності конституційних прав $і$ свобод, зокрема свободи слова в процесі діяльності політичних партій, неурядових організацій та ЗМІ [2]. На основі перерахованих критеріїв Європейська Комісія стверджує, чи в країнахпретендентах демократія має реальний характер. Суттєва роль у становленні демократії відводиться спроможності національних судів захистити фундаментальні права і свободи. Робота судів країн ЄС ґрунтується на демократичних основах.

Серед прав і основоположних свобод було обрано інформаційні, яких у найбільшій мірі потребує становлення демократії і які $є$ найбільш вразливими.

Інформаційні права і свободи людини відносяться до фундаментальних (основоположних). Публікації, в яких висвітлюється зв'язок інформаційних права і свобод людини із становленням 
демократії, носять епізодичний характер, торкаються лише окремих країн $€ C$, і не акцентують увагу на комплексному дослідженні значення згаданих прав і свобод з демократією, спираючись на конституції усіх країн ЄС, що і обумовлює актуальність піднятої проблеми.

Формулювання мети статті та завдань. Метою статті $\epsilon$ встановити значення інформаційних прав і свобод людини для демократії та вияснити особливості їх судового захисту. Для досягнення сфрормульованої мети ставились завдання: розкрити правову суть згаданих прав, визначити їх місце в загальній класифікації прав людини, показати значення для демократії та особливості відстоювання у суді. Поставлені завдання вирішувались на основі дослідження конституцій усіх держав Європейського Союзу.

Виклад основного матеріалу. У результаті проведених пошуків з'ясовано, що інформаційні права притаманні лише людині, адже вони породжуються людською гідністю. Сказане підтверджує Конституція Польщі: «Природна і невідчужувана гідність людини $є$ джерелом свобод і прав людини та громадянина. Вона непорушна, а її повага $i$ охорона є обов'язком публічних влад» [3, ст.30]. Інше підтвердження пропонує Конституція Бельгії: «Життя кожного, достойне гідності, можливе з врахуванням економічних, соціальних і культурних прав» [4, ст.23]. Зауважимо, що інформаційні права входять і до економічних, i до соціальних, і до культурних прав.

Інформаційні права входять і до політичних прав, суттєво впливаючи на якість життя демократичної країни. Підтвердженням може слугувати норма Конституції Люксембургу: «(1) Якість люксембуржця набувається, зберігається та втрачається відповідно до норм, встановлених громадянським законодавством. 
(2)Чинна Конституція та інші закони, які стосуються політичних прав, визначають необхідні умови, крім иієї якості, для здійснення цих прав» [5,ст.9].

Інформаційні права і свободи особи в країнах ЄС належать до основних. Зокрема, у Конституції Мальти: «Оскільки на Мальті кожному належать основні права і свободи, тобто право, ... підпорядковане його обов'язку дотримуватися прав і свобод інших осіб і всезагальних інтересів на будь-яке і на всі з наступних прав, а came:

(в) на свободу совісті, слова, мирних зібрань та об’єднань; і

(c) на повагу до приватного і сімейного життя» [6,ст.32].

Дослідженням встановлено, що в країнах ЄС та США значення інформаційних прав і свобод людини для демократії має спільне підґрунтя.

Спільним у країнах демократії є:

1) інформаційні права і свободи людини забезпечують контролюючу функцію народу над діяльністю держави. Значне число позовів громадян до вітчизняних судів, до ЄСПЛ, вказує на те, що в Україні згадана фрункція реалізується недостатньо. Про те, що в країнах демократії згадані права і свободи забезпечують контролюючу функцію народу над державою підтверджує португальська конституційна норма: «Усі громадяни мають право на отримання об'єктивних відомостей про дії держави і публічних закладів, а також на отримання інформації від Уряду чи інших органів влади про управління громадськими справами» [7,ст.48, п.2]. Підзвітність держави перед народом Франції забезпечує така норма Основного закону: «Суспільство має право вимагати звіту в кожної посадової особи за довірену йому частку управління. ...нехтування прав людини і неповага до них є єдиними причинами суспільних бід і вад Уряду...» [8, ст.15]; 
2) завдяки інформаційним правам і свободам людини забезпечується участь кожного в управлінні країною: «Усі громадяни мають право, особисто або через своїх представників, переконатися в необхідності суспільного оподаткування, вільно давати згоду на нього, слідкувати за його витратами та визначати його розмір, підгрунтя, порядок та тривалість стягування» [8, ст.94];

3) міжнародні договори та акти міжнародних організацій не дають можливості вийти за рамки демократії (в питаннях інфрормаційних прав людини аналогічно - підкреслення автора). Так, Конституція Нідерландів декларує: «Діючі положення законів не застосовуються, якщо їх застосування суперечить загально нормативним положенням міжнародних договорів і актів міжнародних організацій» [9, ст.94];

4) будь-які дії влади, особливо законодавчої, за допомогою інформаційних прав і свобод спрямовуються на врахування інтересів більшої частини населення, що зміцнює демократію: «Будь-яке рішення, що приймається будь-якими органами, як державними, так $i$ суспільними, має базуватись на врахуванні поглядів та інтересів як більшості, так і їі опонентів, перш за все офріційної опозиції, але не тільки ї. А це припускає вільну участь в обговоренні всіх питань максимально широкого кола зацікавлених осіб, а також постійний пошук допустимого компромісу. ... ие сприяє виданню законів, які враховують інтереси більшої частини населення» [10, с.498];

5) обмеження на інформацію можливе тільки для суспільного блага: «Будь-яке (значить, і інформаційне - К.М.) обмеження вільного $і$ рівного доступу до підприємницької діяльності, якщо лише воно не слугує цілям суспільного блага, підлягає усуненню державою» [11, ст.74]; 
6) інформаційні права і свободи є основою суспільного блага (демократії - К.М.). У Конституції Ірландії цей фракт задекларовано нормою: «Держава гарантує свободу здійснення наступних прав за умови дотримання суспільного порядку і моралі: і)право громадян вільно виражати свої судження та думки. Створення суспільної думки $\epsilon$ питанням самої великої важливості для суспільного блага, тому держава прикладе зусилля для забезпечення таких проявів суспільної думки, як радіо, преса, кіно, зображення їх правомірної свободи висловлення, включаючи критику політики Уряду» [12, ст.61ํ];

7) завдяки інформаційним правам і свободам усі забезпечуються об'єктивною інформацією, поширюються витвори літератури і мистецтва, сприяючи культурному розвитку країни. Конституція Греції декларує: «Радіо і телебачення знаходяться під безпосереднім контролем держави; їх діяльність спрямована на об'єктивну і на рівних умовах передачу інформації та відомостей, а також поширення витворів літератури та мистецтва при забезпеченні якісного рівня передач, продиктованого їх соціальною місією та інтересами культурного розвитку країни» [13, ст.15];

8) ці права породжують багатоманітність демократичних думок, демократичний плюралізм, повагу основних прав і свобод забезпечуючи демократію участі. Доказом сказаному $\epsilon$ наступна конституційна норма: «Португальська Республіка - демократична держава, яка грунтується на народному суверенітеті, на багатоманітності демократичних думок i демократичному політичному плюралізмі, на повазі і на гарантіях здійснення основних прав і свобод, на поділі влади та взаємозалежності віток влади, ціллю яких є перетворення демократичних принципів в екологічному, соціальному та культурному житті та поглибленні демократичної участі» [7, ст.2]; 
9) окремі інформаційні права $€$ основою демократичного суспільства; серед них - право на свободу слова, яке реалізується різними способами, має мінімальне обмеження і впливає на усі сторони фрункціонування держави. Конституція Кіпру сказане гарантує нормою: «1. Кожний має право на свободу слова і на його реалізацію будь-яким чином.

2. Таке право охоплює свободу думки, отримання та передачу інформації та ідей, без втручання будь-якої влади незалежно від кордонів» [14, ст.19];

10) інфрормаційні права і свободи надають можливість кожному брати участь не тільки в діяльності держави, а й в діяльності органів самоврядування: «Кожний громадянин Латвії має право передбаченим законом чином брати участь в діяльності держави та органів самоврядування, а також виконувати державну службу» [15, ст.101];

11) інформаційні права і свободи дають змогу кожному впливати ще й на громадські організації та заклади в сорері публічної адміністрації. У Польщі Основний закон сказане гарантує так: «Кожний має право звертатися з петиціями, пропозиціями та скаргами, переслідуючи публічний, власний чи інтерес іншої особи, за їі згодою, до органів публічної влади, а також до громадських організацій та закладів у зв'язку з виконуваними ними завданнями, які їм доручені в сорері публічної адміністрації» [3, ст.63];

12) від інфрормаційних прав і свобод залежить стан та охорона навколишнього середовища: «Кожний має право на інформацію про стан та охорону навколишнього середовища» [Там само, ст.74]. Конституція України [16, ст.50] гарантує кожній людині і громадянину ширші екологічні права і свободи. На відміну від польської, українська норма гарантує відшкодування завданої порушенням екологічного права шкоди. Крім інформації про стан довкілля, вітчизняна гарантує 
право вільного доступу до інформації про якість харчових продуктів і предметів побуту. До того ж, отримана екологічна інформація в Україні вільно поширюється і не підлягає засекреченню. Вільний доступ до екологічної інфрормації та неможливість ії засекречення ставлять екологічні права і свободи в один ряд із основними (пріоритетними). На відміну від польської норми, українська більш зручна для суду у питаннях захисту екологічних прав і свобод: в цій нормі деталізовані свободи, на причетність яких до екологічних у суді не потрібно проводити доведення.

Із наведеного видно, що інфрормаційні права і свободи людини входять, окрім соціальних, політичних, економічних і культурних прав, ще й до екологічних. Місце інфрормаційних прав в загальній класифікації прав людини нами представлено схематично рисунком 1. Враховуючи функції, через які реалізуються інформаційні права і свободи людини в демократичному суспільстві, справедлива блоксхема, подана на рисунку 2.

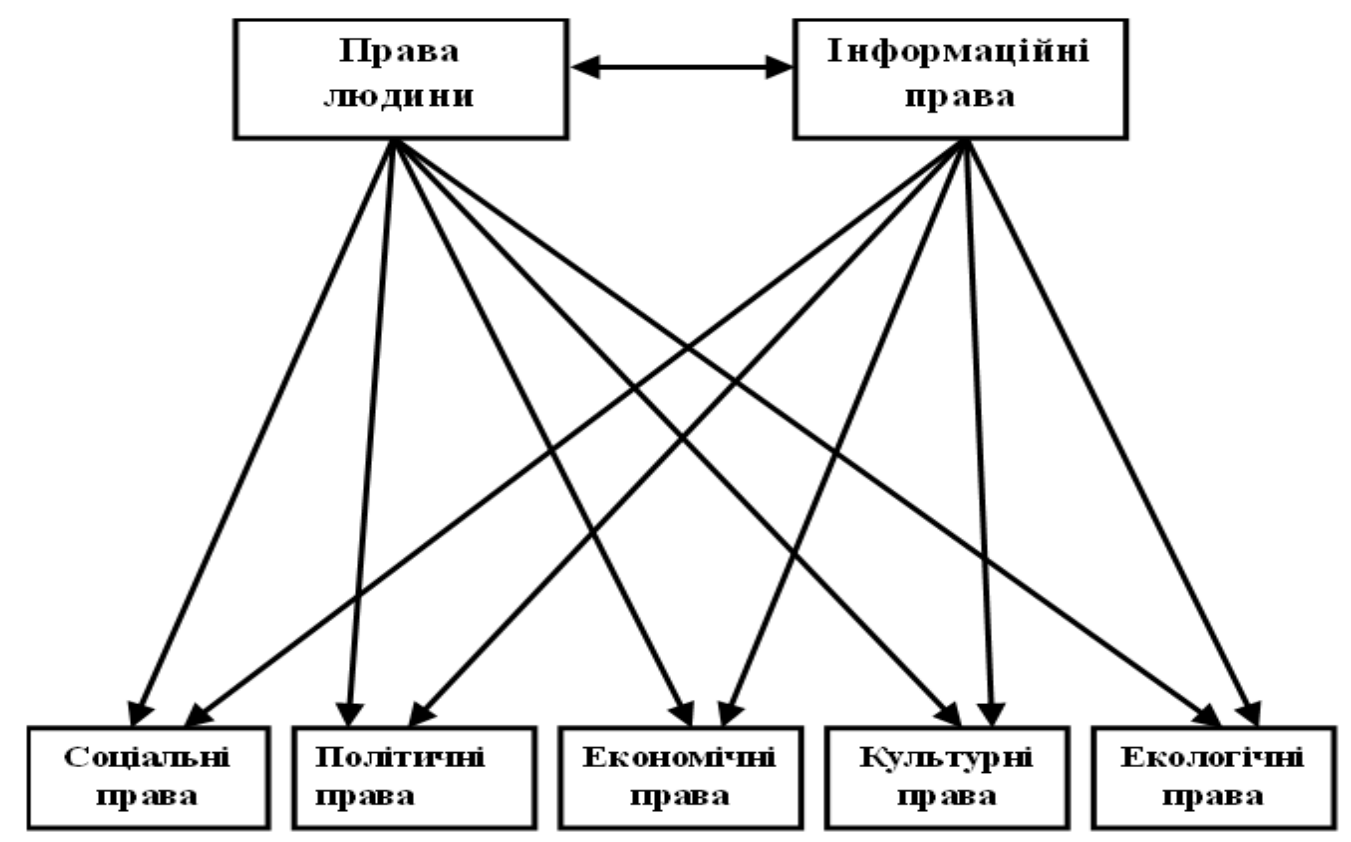

Рис. 1. Місце інформаційних прав в загальній класифрікації 


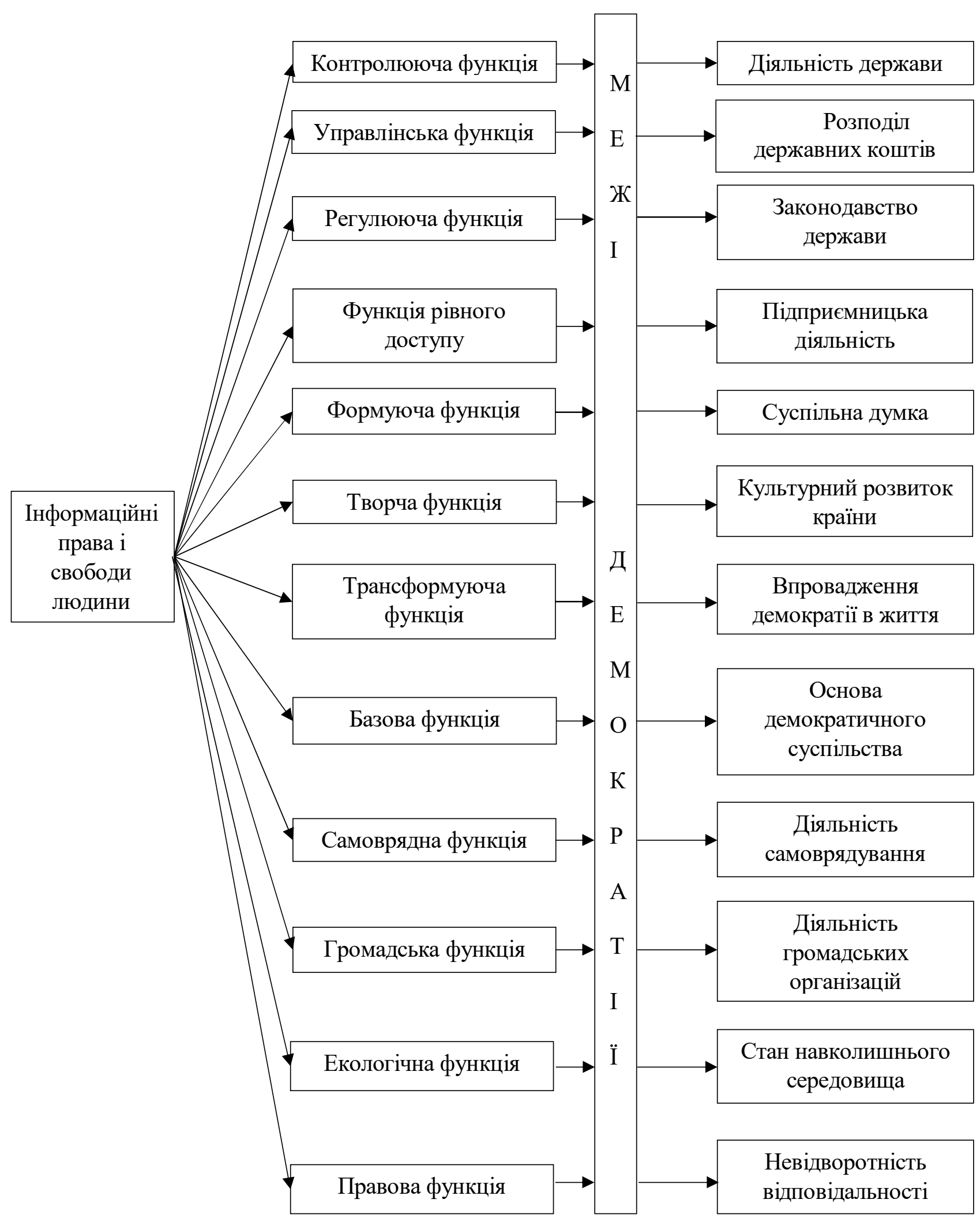

Рис. 2. Значення інформаційних прав і свобод людини в демократичному суспільстві 
Висновки та перспективи подальших досліджень. На основі конституцій країн ЄС розкрито правову сутність інформаційних прав і свобод людини; показано їх місце в загальній класифікації прав людини; визначено функції, завдяки яким інформаційні права і свободи людини впливають на побудову демократичних суспільств; доведено, що судочинство національних судів, які обрали демократичний шлях, має відбуватись на засадах демократії.

На перспективу досліджень виносимо встановлення значення інформаційних прав і свобод людини, їх значення для демократії та особливості захисту в суді, спираючись на Конституцію США, країни 3 повноцінною демократією.

\section{תimepamypa:}

1. Декларация принципов Построения информационного общества глобальная задача в новом тысячелетии. «URL: http://www.gov.Karelia.ru/Leader/Inform/Egov/tunis.htm/» (2017,березень, $6)$.

2. Копенгагенські критерії членства в Європейському Союзі (інформаційно-аналітична довідка).

«URL: http:// www.mfa.gov.ua/ua/page/open/id/774» (2017, березень,7).

3. KONSTYTUCJA RZECZYPOSPOLITEJ POLSKIEJ. Łódź. SAGALARA. 2010.64.

4. La Constitution Belge. Lignes \& entrelignes. Bruxelles. 2004.455.

5. Люксембург. Конституція (2001). Конституции государств Европы:

В 3 т. Т.2. Москва. НОРМА. $2001.402-418$.

6. Конституция Республики Мальта. Конституции государств Европы:

В 3 т. Т.2. Москва. НОРМА. 2001.468-644.

7. Constituição da República Portuguessa. 2010.343. 
8. Constitution française du 4 octobre 1958 après la révision de juillet 2008.

9. Фінляндія. Конституція (2000). Конституции государств Европы: В 3т. Т.3. Москва. НОРМА. $2001.371-400$.

10. Музичук К.С. (2015). Демократичні основи захисту інфоормаційних прав людини в Суді. Луцьк: Вежа-Друк.

11. Данія. Конституція (1953). Конституции государств Европы: В Зт. T.1.Москва. НОРМА, 2001.761 - 773.

12. Ірландія. Конституція (1937). Конституции государств Европы: В 3т. Т.1. Москва. НОРМА, 2001.502 - 522.

13. Греція. Конституція (1975). Конституции государств Европы: В Зт. Т.1. Москва. НОРМА.2001.646 - 696.

14. Кіпр. Конституція (1960). Конституции государств Европы: В Зт. Т.2. Москва. НОРМА.2001.210 - 285.

15. Latvijas repudlikas satversme. Riga. AFS. 2008. 18.

16. Конституція України(2004): Основний закон: із змінами, внесеними згідно із Законом № 2222- IV від 8 груд. 2004 р. Харків: ФОП Співак T.K.2009.48.

\section{References:}

1. Deklaracy'ya pry'ncy 'pov Postroeny ya y'nformacy`onnogo obshhestva - global'naya zadacha $v$ novom tbsyachelety'y' [The Declaration of Principles for Building the Information Society is a global challenge in the new millennium] Petrieved from http://gov.Karelia.ru/Leader/Inform/Egov/tunis.html. [in Russian] (2017, March, 06).

2. Kopengagens`ki kry`teriyi chlenstva $v$ Yevropejs`komu Soyuzi (informacijno-anality chna dovidka) [Copenhagen criteria for membership in the European Union (information and analytical information)] Petrieved 
from http:// www.mfa.gov.ua/ua/page/open/id/774. [in Ukrainian](2017, March, 07).

\section{KONSTYTUTSIYA RESPUBLIKY POL'SHCHA.Łódź.SAGALARA.} 2010.64 [CONSTITUTION OF THE REPUBLIC OF POLAND. Lodz. SAGALARA. 2010.64.] [in Polish].

4. Konsty'tuciya Bel'giyi.Bryussel'. 2004.455 [The Constitution of Belgium. Brussels.2004.455] [in Belgian].

5. Lyuksemburg. Konsty'tuciya (2001). Konsty'tuciyi derzhav Yevropy': U 3

t. T.2. Moscow. NORMA. $2001.402-418$ [Constitution of the European States: 3 t. T.2. Moscow. NORM. 2001.402 - 418] [in Russian].

6. Mal'ta. Konsty'tuciya (1964). Konsty 'tuciyi derzhav Yevropy': U 3 t. T.2. Moscow. NORMA. 2001.468-644 [Constitutions of European States: In $3 \mathrm{t}$. T.2. Moscow. NORM. 2001.468-644] [in Russian].

7. Portugaliya. Konsty'tuciya (1976) [Constitution of the Republic of Portugal.2010.Porto.Almedina] [in Portuguese].

8. Franciya. Konsty'tuciya (1958). Konsty'tuciya Franciyi vid 4 zhovtnya 1958 roku pislya pereglyadu ly' pnya 2008 roku [The French Constitution of 4 October 1958, after revision of July 2008. Pariz.] [in French].

9. Finlyandiya. Konsty'tuciya (2000) [The Constitution of Finland (2000).Helsinki] [in Finnish].

10. Muzy'chuk K.S. (2015). Demokraty'chni osnovy' zaxy'stu informacijny'x prav lyudy'ny' $v$ Sudi. Lutsk: Vezha-Druk [Muzychuk K.S. (2015). Democratic Foundations for the Protection of Information Rights in the Court. Lutsk: Tower-Print] [in Ukrainian].

11. Daniya. Konsty'tuciya (1953) [The Constitution of Denmark(1953).Copenhagen.] [in Danish].

12. Konsty'tuciya Irlandiyi (1937) Konsty'tuciyi derzhav Yevropy': U 3 t. T.1. Moscow. NORMA. $2001.402-418$ [Constitution of the European States: 3 t. T.2. Moscow. NORM. 2001.646 - 696] [in Russian]. 
[Ireland. Constitution (1937)] [in Russian].

13. Greciya. Konsty tuciya (1975) Konsty tuciyi derzhav Yevropy`: U 3 t. T.2. Moscow. NORMA. 2001.402 - 418 [Constitution of the European States: 3 t. T.2. Moscow. NORM. 2001.402 - 418] [in Russian].

[Greek Constitution (1975)] [in Russian].

14. Kipr. Konsty tuciya (1960) Konsty tuciyi derzhav Yevropy` U 3 t. T.2. Moscow. NORMA. $2001.402-418$ [Constitution of the European States: 3 t. T.2. Moscow. NORM. 2001.210 - 285] [in Russian].

[The Constitution of Cyprus (1960)] [in Russian].

15. Latviya. Konsty tuciya (2013) [Latviya. Konsty tuciya (2013).Riga] [in Latvian].

16. Konsty `tuciya Ukrayiny`: Osnovny`j zakon: iz zminamy`, vneseny’my` zgidno iz Zakonom \# 2222- IV vid 8 grud. 2004 r. Kharkiv: FOP Spivak T.K.2009.48 s [The Constitution of Ukraine: Basic Law: as amended in accordance with the Law No. 2222-IV of 8 December. 2004 Kharkiv: FOP Spivak T.K.2009.48 p.] [in Ukrainian]. 